\title{
Is dialogic teaching sustainable? Portrait of a teacher three years after completing a teacher development programme
}

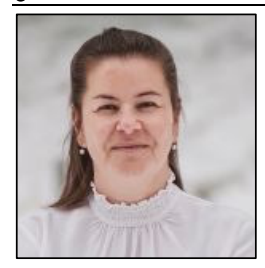

Klara Sedova

Masaryk University, Czech Republic

\begin{abstract}
This study deals with the question of whether a change in classroom discourse implemented through teacher professional development (TPD) is sustainable over time. I studied one teacher's practices and thinking three years after completing a TPD programme focused on dialogic teaching. The data were collected through interviews with the teacher and video recordings of her lessons. The data showed that the teacher continued with dialogic teaching, but she appropriated and modified the concept of dialogic teaching to serve her own needs and preferences. The way the teacher overcame obstacles to sustaining the implemented change is discussed in the study. ${ }^{1}$
\end{abstract}

Klara Sedova is a Professor in Education at Masaryk University in the Czech Republic. She is leading a research team that has been working for more than ten years in the field of classroom dialogue and interaction studies. The team has conducted ethnographic observations in Czech schools as well as interventional studies and large-scale surveys. Currently, She is interested in the link between individual student talk during lessons and the learning achievements of those students. Email: ksedova@phil.muni.cz

\section{2बS}

\section{Introduction}

It has been repeatedly claimed that a student-centered approach based on positioning students as social agents and active learners remains rare in contemporary classrooms, which are dominated by rote memorization and textbook work (Crick et al., 2007; Mameli et al., 2020). One instructional approach being regarded as promising in enhancing student learning through their agentic participation in classroom talk is dialogic teaching (Alexander, 2020). On that account, many professional development programs have been initiated in this field in the past three decades. Some of these programs were remarkably successful, and the participating teachers managed to establish productive dialogue in their classrooms (see, e.g., Alexander, 2018; Hennessy et al., 2018; O'Connor et al., 2015; Osborne et al., 2019; Schwarz et al., 2017; Sedova et al., 2016). However, the issue of the sustainability of the change in teaching was rarely discussed in these studies. The aim of this paper is to contribute to filling this significant knowledge gap. I present a case study of one teacher who participated in a teacher development programme focused on implementing dialogic teaching in the 2014/2015 academic year and who changed her teaching practices as a result of the programme. The same teacher was observed three years later to explore the extent to which this

${ }^{1}$ This article is an output of the project Collectivity in Dialogic Teaching: An Intervention Study (GA21-16021S) funded by the Czech Science Foundation. 
change was preserved. This paper addresses the question of whether dialogic teaching is sustainable in ordinary lessons after the teacher has lost the support provided during a teacher development programme.

\section{Theoretical background}

\section{Dialogic teaching as a difficult-to-attain ideal}

Dialogic teaching is a pedagogical approach utilizing the power of talk to engage students, stimulate and extend their thinking, and advance their learning and understanding (Alexander, 2020). In dialogic teaching, the teacher does not deliver pieces of information to students; rather, the teacher and students co-construct new knowledge together (Mercer, 2008).

The concept of dialogic teaching stems from the sociocultural theory related to the work of Vygotsky (1978), who postulated that there is a clear connection between speech and thought. In this view, our inner mental abilities come from the outside (Vygotsky, 1978); all human knowledge is of a social nature and is created by previous social participation (Wertsch, 1985). The theory of dialogic teaching was also inspired by Bakhtin's (1981) theory of speech genres. Bakhtin differentiated between two speech genres: authoritative and dialogic discourse. The aim of the former is to persuade, mediate knowledge that is considered true, and ensure the reproduction of such knowledge. In essence, the aim of authoritative discourse is to convince its audience to accept the perspective of the speaker. In contrast, dialogic discourse opens space for various perspectives, ideas and aims to provide stimuli for thinking. Different voices, or perspectives, take turns in speaking in dialogic discourse.

Dialogic teaching as an instructional approach thus emphasizes verbal interaction between teachers and students in a class in which different voices animate each other (Bakhtin, 1981). Students use specific talk moves - they speak in long and elaborate utterances that include arguments and reasoning words; they express their authentic ideas, explain their thinking, actively listen to the ideas of others, and engage in thinking about these ideas. Teachers support student participation in classroom dialogue through their talk moves: they ask open-ended and cognitively demanding questions that fuel open discussion (with peer interaction established) and invite students to analyze, generalize, and speculate rather than simply look for facts or review already learned knowledge; they build on what was said by students, paraphrase, summarise, and elaborate student utterances, give them uptake, and ask contingent questions (see, e.g., Alexander, 2020; Lyle, 2008; Kim \& Wilkinson, 2019; Sedova et al., 2016; Vrikki et al., 2019; Wilkinson et al., 2015).

Also, specific general principles of dialogic teaching needed to be heeded by the teacher. According to Alexander (2020), classroom dialogue must be (1) collective (all students should participate); (2) reciprocal (teachers and students should listen to each other and share thoughts); (3) supportive (no fear about expressing one's own ideas); (4) deliberative (aiming to resolve different points of view); (5) cumulative (knowledge should be accumulated through dialogue); and (6) purposeful (dialogue should serve given educational goals).

A substantial body of empirical evidence shows that dialogic teaching positively impacts learning (see, e.g., Alexander, 2018; Andreassen \& Bråten, 2011; Applebee et al., 2003; McElhone, 2012; Muhonen et al., 2018; O'Connor et al., 2015). In spite of this, the research on actual school practices overwhelmingly shows that the prevalent forms of teaching are far from dialogic ideals (see, e.g., Alexander, 2008; Hardman et al., 2003; Berry \& Kim, 2008; Nystrand et al., 1997; Sedova et al., 2014). The dominant form of instruction is still transmissive and monological, where the teachers present certain facts to students and then, through closed-ended questions, briefly check whether students have learned these facts (Riesman et al., 2018; Wells \& Arauz, 2006). 


\section{Teacher development programs as a tool for delivering dialogic teaching to classrooms}

Teacher professional development (TPD) is a tool for improving the quality of teaching (Gore et al., 2017). Not surprisingly, many TPD projects have been created to introduce dialogic teaching into schools over the past three decades (e.g., Alexander, 2018; Hennessy et al., 2018; Lefstein \& Snell, 2014; Osborne et al., 2019; Schwarz et al., 2017; Sedova et al., 2016). Some of these projects reported only limited or no outcomes; others were successful. According to Wilkinson et al. (2015), the successful programs shared an element of reflection on teaching practices through video recording and transcripts, co-inquiry and coplanning of lessons, and a dialogic approach to professional development.

However, even studies based on successful projects have claimed that shifting teaching practices towards dialogic teaching was not an easy task for teachers, as it demanded a lot of effort and support (Gomez Zaccarelli et al., 2018; Sedova, 2017; Snell \& Lefstein, 2018). Also, in some studies, the authors concluded that although they assessed the teachers as thriving in the practice of dialogic teaching, it does not mean they mastered all the elements of the dialogic teaching addressed by the particular intervention program (Sedova, 2017; Chinn et al., 2001; Nassaji \& Wells, 2000; Gomez Zaccarelli et al., 2018).

These observations may arouse some concerns about the sustainability of change accomplished during TPD. What happens to the teachers after the support of the researchers and educators is gone? Will teachers gravitate back to their former ways of teaching? Doubts about the long-term impacts of TPD were explicitly expressed by Hennessy and Davies (2020). These authors also hypothesized three general reasons that limit the impact of TPD: (1) the complex change in teaching is too demanding for the teachers, and they do not develop all the needed abilities during the training time; (2) the shift from traditional practice is not trivial, requiring a change of teacher mindset, which does not always happen during the TPD; and (3) teachers do not really believe in what they were taught during TPD; they do not find it sufficiently informative, persuasive, nor valuable.

For the dialogic teaching movement, it is absolutely essential to examine these concerns. If the quality of teaching changes only temporarily, and the changes are not sustainable, then investing effort and money in TPD focused on dialogic teaching is in vain. Unfortunately, there is nearly no data about the longterm impact of dialogic teaching TPD initiatives. To my knowledge, few studies have investigated the sustainability of dialogic teaching. Chen (2020) conducted TPD focused on changes in teachers' beliefs in the usefulness of classroom talk as well as in their self-efficacy in guiding the classroom talk and on enhancing teachers' ability to encourage student elaboration, reasoning, and thinking with others in the classroom. The teachers in the intervention changed both their beliefs and their teaching practices. In a delayed post-test after three terms, the sustainability of the teachers' beliefs and self-efficacy was verified. However, the sustainability of teacher teaching practices was not examined.

The sustainability of dialogic teaching practices was examined by Hennessy et al. (2018), who reported observing two teachers who continued using a dialogic approach ten weeks after they completed a TPD program (see also Hennessy \& Davies, 2020). More elaborated findings were published by Osborne et al. (2019), who conducted a TPD program to enhance elementary teachers' ability to engage their students with argumentation in science. The data were gathered longitudinally (over four years in total), with the last collection one year after the end of the TPD program. The authors found a rapid increase in dialogic teaching practices in the first year of teachers' participation in TPD, then the pace of change decelerated. When measured one year after completing the programme, the values of indicators were lower than during the programme, although still higher than before the programme started. Osborne et al. (2019) concluded that changes in teaching practices might be difficult to sustain. Newly mastered teaching skills may fade without additional TPD opportunities and support. 


\section{The present study}

The aim of this study is to explore the issue of the sustainability of a shift towards dialogic teaching through a case study of one teacher. The teacher participated in a TPD program in the 2014/2015 academic year (Study 1). I was a researcher closely cooperating with this teacher during TPD, and I analyzed the data about her learning development in depth to find what was the result of her participation in the program (see Sedova, 2017). In 2018, I had the opportunity to cooperate with the same teacher again, video record her lessons, and interview her (Study 2). This resulted in rich data, allowing me to compare how this teacher approached teaching before, during, and at the end of the TPD programme, as well as several years after its completion. With regard to the scarcity of studies investigating the long-term impact of TPD on dialogic teaching, this dataset is worth a thorough examination.

The following questions guide the analysis:

$R Q$ 1. How does the teacher's classroom discourse compare with her discourse three years earlier when she finished the TPD program?

$\mathrm{RQ}$ 2. What did the teacher think about dialogic teaching three years after completing the TPD programme?

\section{Methods}

\section{The focal teacher and her classes}

The teacher Daniela ${ }^{2}$ worked at a lower secondary school (ISCED 2A) ${ }^{3}$ in a big city in the Czech Republic. The school was attended predominantly by children from working-class and middle-class families. Daniela had 12 years of teaching experience at the time of Study 1; she had 15 years of experience at the time of Study 2. She taught the Czech language, language arts, and history, but for the research project, she was observed only in the language arts lessons.

During Study 1, Daniela was observed with the seventh grade: the class was attended by 20 students, average age 13 years, 11 girls and 9 boys. Study 2 took place in the ninth grade, with 13 students attending the class, average age 15 years, 4 girls and 9 boys.

\section{Design of Study 1 and Study 2}

Study 1

Study 1 was designed as an intervention through a TPD program. Eight teachers from five lower secondary schools participated in the program. When designing the TPD program, we, the researchers, were aware that successful intervention requires dialogic reflection on teaching practices through video recording and co-planning of lessons by both the teacher and the researcher (Wilkinson et al., 2015). Therefore, the development program included several components: 1) four workshops for the teachers (each lasting three hours); 2) documentation of their lessons using video recording (10 lessons lasting 45 minutes of each teacher); and 3) reflective interviews led by a researcher with a teacher (8 interviews with each teacher, each lasting 60 to 90 minutes). The duration of the program was eight months (beginning in November and ending in June).

\footnotetext{
${ }^{2}$ This is a pseudonym - see the section on Research Ethics below

${ }^{3}$ Compulsory education in the Czech Republic lasts nine years and includes elementary schooling (Grades 1 to 5 ) and lower secondary schooling (Grades 6 to 9).
} 
During the workshops, participating teachers were familiarised with the theoretical background of dialogic teaching and its features and principles. During the reflective interviews, a stable teacherresearcher pair watched and commented on the video recording of a previous lesson and planned how to approach the next lesson. Generally, teachers were encouraged to incorporate the following indicators of dialogic teaching into their lessons: (1) student thoughts with reasoning (Pimentel \& McNeill, 2013) - a student's utterance with characteristics of a sentence, including an argument or reasoning; (2) teacher's open questions of high cognitive demand - authentic questions requiring cognitive operations of a higher level than memorization, aimed at revealing a student's ideas and opinions, and for which there is no set answer (Gayle et al., 2006); (3) uptake - a situation in which the speaker builds on what has been said by the previous speaker; typically, a teacher creates a follow-up question based on a student's answer (Nystrand, 1997); (4) student questions (Nystrand et al., 2001); and (5) open discussion - a sequence that includes at least three participants who respond to each other for more than 30 seconds (Nystrand, 1997). The principles of dialogic teaching, as established by Alexander (2006), were also introduced to the teachers. The researchers stressed dialogue to be collective, reciprocal, supportive, cumulative, and purposeful; this was extensively discussed during workshops and reflective interviews.

As for analysis, the research team monitored the presence of the indicators of dialogic teaching in the series of lessons and compared video recordings of participating teachers before they entered the program, during the program, and after they completed it. The TPD was considered to have been successful, as the teachers strengthened indicators in their lessons (for details, see Sedova et al., 2016).

Study 2

The aim of Study 2 was to investigate the relationship between student participation in classroom talk and their achievement in the ninth grade (see Sedova et al., 2019). The research was conducted under natural conditions on a sample of 32 classes (639 students). In each class, the research team conducted a systematic observation of classroom dialogue, at the same time collecting data about student achievement. The sample was constructed by the Czech School Inspectorate (CSI), which is a key central institution in the evaluation of the education system in the Czech Republic. It was a lucky coincidence that a class taught by Daniela was included in the sample.

Subsequently, the research team selected four classes for in-depth research focused on individual student participation in classroom talk. The data collection consisted of video recordings of lessons (six in each classroom), interviews with teachers (two with each teacher), and group interviews with students (four in each classroom). When being video recorded, teachers were instructed to teach as they usually do. The aim was to capture standard lessons with customary student talk behavior.

Daniela agreed to participate in this part of Study 2, and I was again nominated to be a researcher in close contact with this teacher (making video recordings and interviewing the teacher and the students). This made it possible to analyze data to consider how dialogic Daniela's teaching was three years after the TPD programme concluded.

\section{Data and the analysis}

This paper analyses data gathered during Study 2 - video recordings of lessons and interviews with the teacher. Six video recordings of Daniela's teaching were made during the study. Four of them were made in language arts lessons, and two of them were made in Czech language lessons. In this study, I use only data from the language arts lessons ( $4 \times 45$ minutes) to make the material comparable to the data from

Study 1. Further, two interviews with the teacher were conducted during Study 2, the first before the video recording started (50 minutes) and the second after the video recording finished (65 minutes). 
I compare data gathered during Study 2 with data from Study 1 . Study 1 collected ten video recordings of language arts lessons ( $10 \times 45$ minutes) and six interviews with the teacher (lasting 45 to 60 minutes). The overview of data sources is in Appendix 1.

To address RQ 1, I coded the video recording of the lessons included in Study 2 the same way that the data in Study 1 were formerly coded (see Sedova et al., 2016). During Study 1, a deductive set of codes was used, representing the individual indicators of dialogic teaching: student thoughts with reasoning, teacher's open questions of high cognitive demand, uptake, student questions, and open discussion. An overview of the coding system with examples and illustrations is presented in Appendix 2. The unit of analysis was one lesson. The absolute incidence of each indicator was counted for each individual lesson. The duration of open discussion was measured in minutes. When coding, only those parts of the lessons that involved interaction between the teacher and students were included. Students' reading, individual work, and group work were excluded. The coding in Study 1 was done by four pairs of coders who were thoroughly trained in recognizing individual indicators. Prior to the start of the analysis, each coder practiced identifying each indicator using older video recordings that were available to the research team, individually and in a supervised group. The training was finished when agreement among all coders reached $90 \%$; this took about 60 hours per coder. During the analytic stage, each lesson was coded by one pair of coders who worked independently and subsequently compared their codes; inconsistencies were solved through discussion.

During Study 2, I used the same set of codes. I coded the lessons the same way as in Study 1. My coding was checked by a member of the research team who had worked on Study 1, Roman Švařiček. The inconsistencies were rare (less than $8 \%$ ) and were solved through discussion.

To address RQ 2, I analyzed data from interviews using the ATLAS.ti software for qualitative data analysis. I coded the material using a three-step procedure. In the first - deductive - phase of coding, I proceeded from the Hennessy and Davies (2020) clusters of dialogic teaching obstacles (see section on Teacher development programs). Therefore, I searched in the data for passages reporting on (1) the complexity of the change, (2) teacher mindset, and (3) (dis)trust in dialogic teaching. In the second inductive - phase, I applied open coding based on the grounded theory approach (Strauss \& Corbin, 1990) to create fine-grained inductive codes inside these three broad clusters. I created 69 inductive codes in total. In the third phase, I used selective coding (Strauss \& Corbin, 1990) to re-categorize the inductive codes according to their affinity to three categories: (1) educational goals; (2) students; and (3) teacher selfperception. These categories represent a subject domain of change as seen by the teachers. These finally established categories correspond with our findings. The coding procedure is depicted in Appendix 3.

\section{Research ethics}

In both studies, I first obtained the consent of the teacher Daniela and her school principal. Subsequently, I asked for and was granted written consent from all parents to the participation of their children in the research. All data were carefully anonymized. All participants were assigned pseudonyms under which they appear in the published studies. All participants were assured of data confidentiality and the ability to withdraw from the research at any time. No one withdrew during the research.

\section{Limitations of the study}

This study has some obvious limits. Some are due to the research design - a case study with repeated data gathering. First, only one teacher was observed, which makes the results provisional, calling for an examination of the findings on a larger teacher sample. Also, we should be clear concerning some particular characteristics of the participating teacher before we interpret the findings from this case. Daniela 
is an example of a teacher who was in favor of a dialogic approach before entering TPD. Moreover, she entered the TPD program voluntarily and was successful in implementing the changes required by the program. This is why the same findings cannot be expected with teachers who are in opposition to dialogic teaching, enter TPD by command, or do not successfully implement it. Therefore, not only do we need a bigger sample in the future, but also a sample consisting of teachers with variable professional experience and attitudes to dialogic practice and self-efficacy.

Second, the analysis in this study is based on a comparison of data from $2014 / 2015$ and 2018 . The results are weakened by the fact that Daniela did not teach in the same class in both series. Some of the differences can proceed from different characteristics of the two classes, including the different ages of the students. However, this is a methodological puzzle - when coming back to the TPD-leavers after some time; we have no option but to observe them in different classes and/or altered conditions.

The other limitation of this study is due to the analytic approach. In order to compare data representing classroom dialogue in different time sections, I used a set of measurable indicators of dialogic teaching. This approach is legitimate but necessarily reductionist as the list of indicators can never fully embody the nature of classroom dialogue. In addition to this, the numeric values of individual indicators cannot be understood as determinative for encompassing the quality of dialogic teaching. Therefore, a more detailed qualitative analysis of observational data needs to be conducted in the future as a complement to the analysis presented in this study.

\section{Findings}

\section{Daniela's 2018 teaching at a glance}

For an illustration of the classroom talk at the time of Study 2, I am providing an excerpt from the first lesson in this series. The class had read aloud a passage from the book Sophie's World by Jostein Gaarder dealing with ancient Greek philosophy. Reading was followed by a discussion about the text.

Excerpt 1: Lesson 1, Study $2^{4}$

1. Teacher: The philosopher Socrates thought that a slave is just as educable as a literate citizen. (3) Do you think this could be true?

2. Katka: Yup.

3. Veronika: Well, it is. If he wasn't a slave, he would be the same human like all others, having the same education and so on.

4. Michal: But the slave could be absolutely stupid. Then he would be hard to educate.

5. Teacher: Why do you think he is stupid?

6. Michal: Can be.

7. Teacher: Can be, but why do you say he could be stupid?

\footnotetext{
${ }^{4}$ For transcipt conventions, see Lefstein \& Snell (2014).
} 
8. Michal: Don't know. The same with the citizen. Both can be stupid. It's about in what class they were born.

9. Radek: Well, the slave can just appear stupid. It could be because he hadn't learned anything since he was born.

10. Tomas: Being from a poor family.

11. Teacher: So, isn't it more probable that an educated citizen will understand the philosopher more accurately? (3)

12. Veronika: The uneducated can understand, too. ((Student Radek nodding his head))

13. Teacher: ((smiling)) Well, Socrates evidently thought so. From time to time, he was talking to slaves, and he expected them to understand.

The excerpt has many attributes of dialogic teaching (see section on Dialogic teaching as a difficultto-attain ideal). The students are heading towards authentic thinking and participation. Together with the teacher, they co-construct new knowledge (Mercer, 2008). In terms of talk moves, there are student thoughts with reasoning (lines 3,9), teacher's open questions of high cognitive demand (line 1), uptake (lines 5,7), and open discussion (the whole excerpt). Also, principles of dialogic teaching (Alexander, 2020) are clearly kept - the conversation is linked to a deep interpretation of a literary text (purposefulness), many students are involved (collectivity), there is no fear of expressing one's thoughts, and students even contradict the teacher (supportivity), the speakers obviously react to each other (reciprocity), and build on each other's utterances (cumulativity).

\section{Changes in the characteristics of the classroom dialogue}

In this section, I address RQ 1, looking for what changed from Study 1 to Study 2 primarily in terms of indicators of dialogic teaching. I utilize the data from the videorecordings collected in 2014/2015 and 2018.

\section{Comparison of pre, post, and follow-up lessons}

In Figure 1, I compare some features of Daniela's teaching before she entered the teacher development programme (pre lessons, $n=2$ ), at the end of the programme (post lessons, $n=2$ ), and three years later (follow-up lessons, $n=4$ ). The vertical axis shows the average values of individual indicators of dialogic teaching per one lesson in the pre, post, and follow-up phases.

The open discussion indicator is measured in minutes. Values of all the remaining indicators state the absolute number of occurrences of the given indicator per one lesson. 
Figure 1: Comparison of pre, post, and follow-up lessons in indicators of dialogic teaching
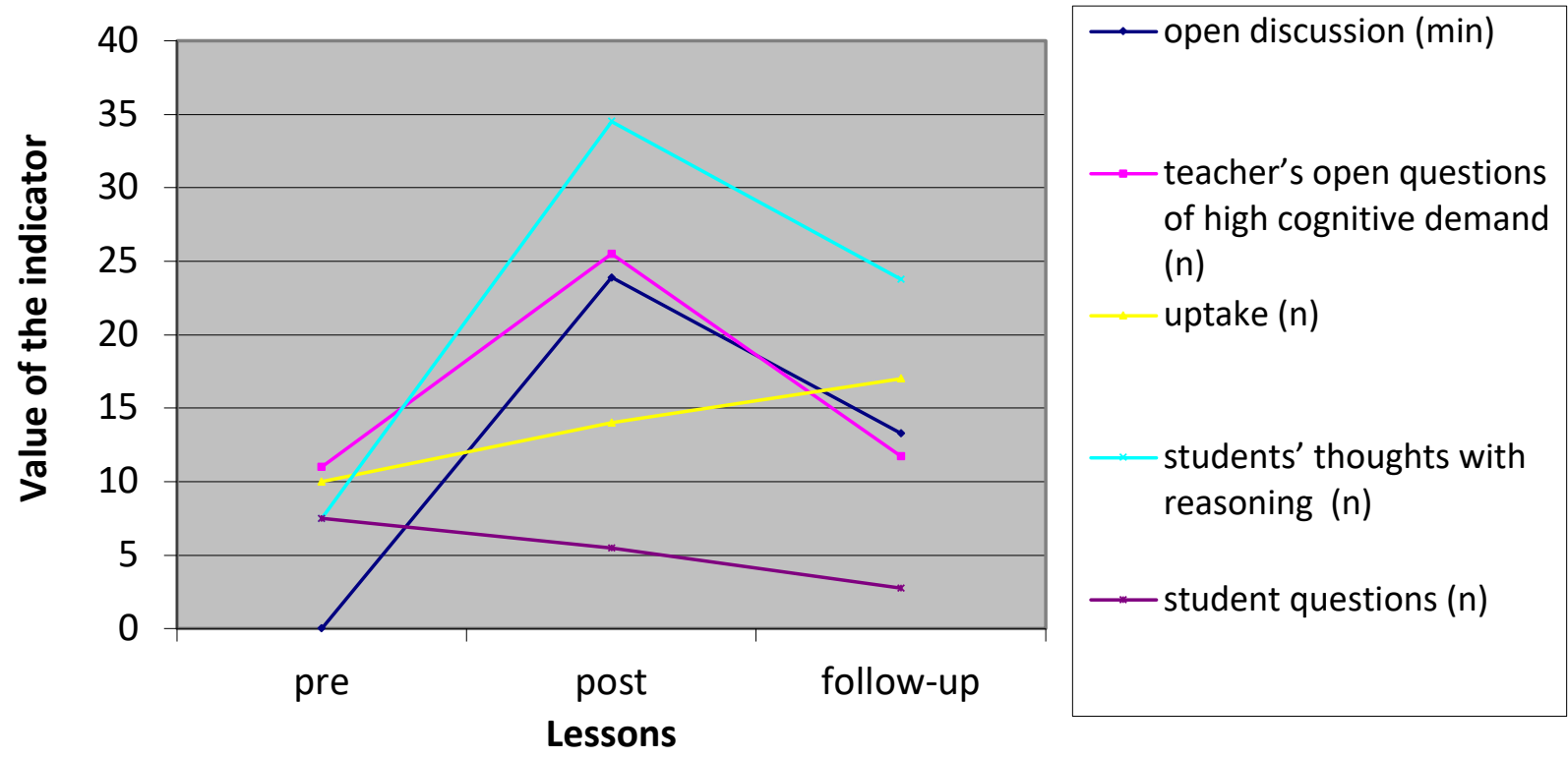

The trend is not the same for all indicators. The open discussion and student thoughts with reasoning show the same pattern: a rapid increase between pre and post lessons and a moderate decrease between post and follow-up lessons. Teacher's open questions of high cognitive demand increased heavily due to the program, but three years later, they were used with very similar frequency as before the program had started. Uptake increased only mildly between pre and post lessons, but the increase continued over time, reaching its maximum in the follow-up lessons. By contrast, student questions decreased continually from pre to follow-up lessons.

In a nutshell, Figure 1 gives no simple answer to the question about the sustainability of the change. Some things from what the teacher had learned in the program strengthened over time (uptake); some things remained, but not in the top form (open discussion and student thoughts with reasoning); and some things seemed to be lost (teacher's open questions of high cognitive demand, student questions). Before I start with a more subtle analysis, I want to stress that during the program, we placed the strongest emphasis on the indicator of student thoughts with reasoning, which we considered to be the most prominent and reliable feature of dialogic teaching (see Sedova et al., 2016). With this in mind, we can say that the most important gain from the development program was sustained, even though not in its top form.

\section{A closer exploration of the individual lessons in both series}

In figures 2 and 3 we can see the incidence of indicators of dialogic teaching in Daniela's lessons during the teacher development programme (Figure 2) and three years after its completion (Figure 3). 
Figure 2: Development of dialogic indicators during Study 1 (November 2014 - May 2015)

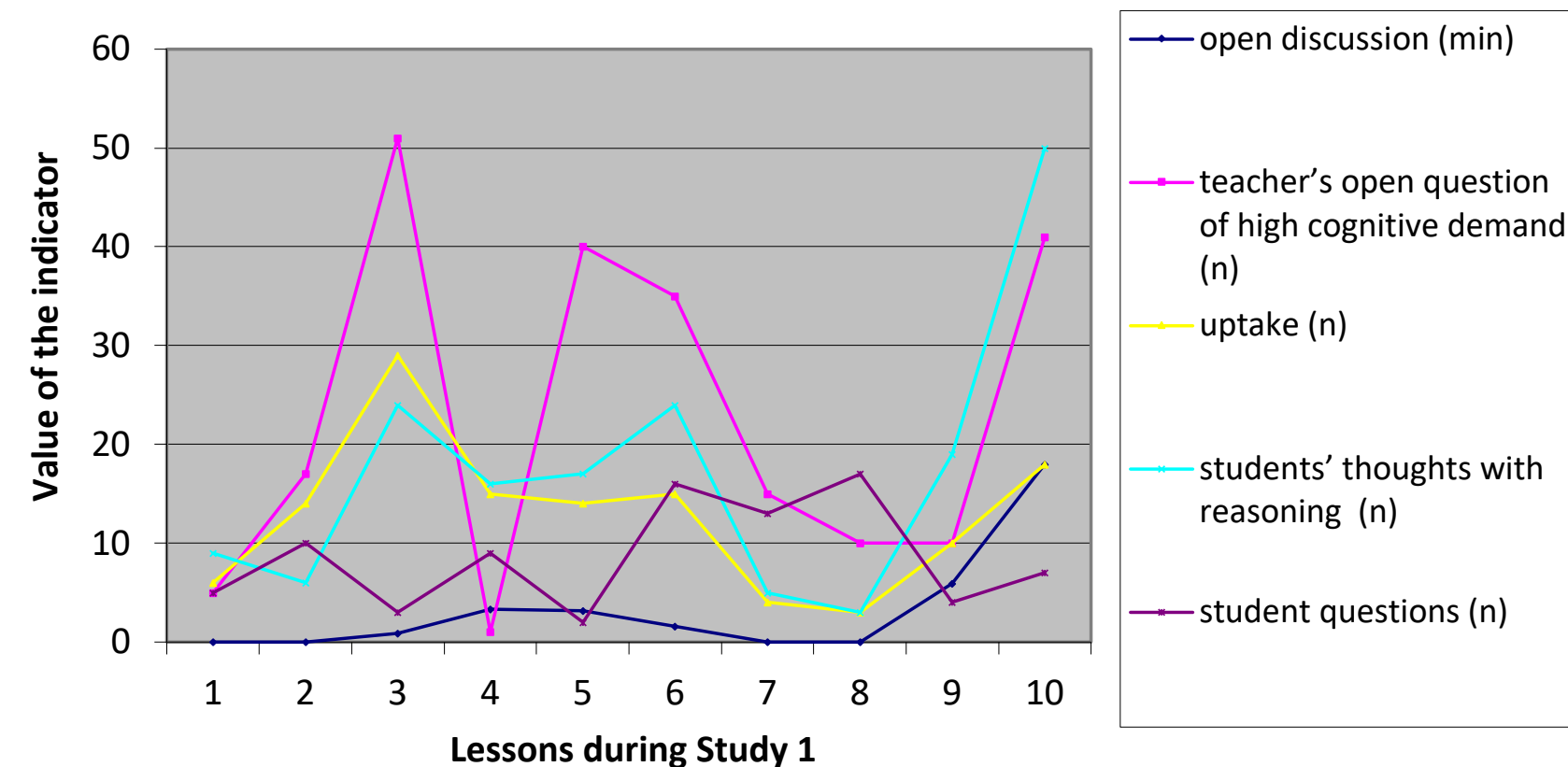

Figure 2 reveals an observation that remains hidden when simply comparing average values in pre lessons $(1,2)$ and post lessons $(9,10)$. The change in the parameters of the classroom dialogue during the teacher development programme was not of a linear nature. It is clear that a smooth, gradual growth of individual indicators did not take place over time; the change happened in jumps, some of which have the characteristics of a regression. There are two points in the diagram where the values of most indicators visibly drop. One is in Lesson 4; the other is in Lessons 7 and 8 . In contrast, there are some apparent peaks - in Lessons 3 and 6 and most obviously in Lesson 10, the final lesson. Lesson 10 can be labeled as extreme - there are more than twice as many occurrences of student thoughts with reasoning as in other lessons; other indicators are also very high.

It is evident from Figure 2 that during TPD, it was not easy for Daniela to maintain the levels of all the measured indicators. Sometimes she was successful; sometimes not. During the whole series of lessons, the teacher used a variety of instructional methods (e.g., student role-playing, incomplete lecture with space for student questions, creating and re-creating stories in peer groups, and student presentations of books); she knew some methods from past experience, some were presented during the workshops for teachers, and some she creatively fashioned herself. The chosen methods did not always work as Daniela intended, which repeatedly led her to abandon or modify them (for details, see Sedova, 2017).

The final two lessons at the end of the program were - in terms of indicators - very good or even excellent. When analyzing the case of the teacher Daniela after the TPD program had ended, I evaluated her as very successful in mastering dialogic teaching (see Sedova, 2017). But the question of the sustainability of the change remained open. There was no guarantee that the peak in Lesson 10 would not be followed by another massive drop. Utilizing the new portion of data collected in 2018 , I can now address this question. 
Figure 3: Development of dialogic indicators during Study 2 (February 2018 - May 2018)

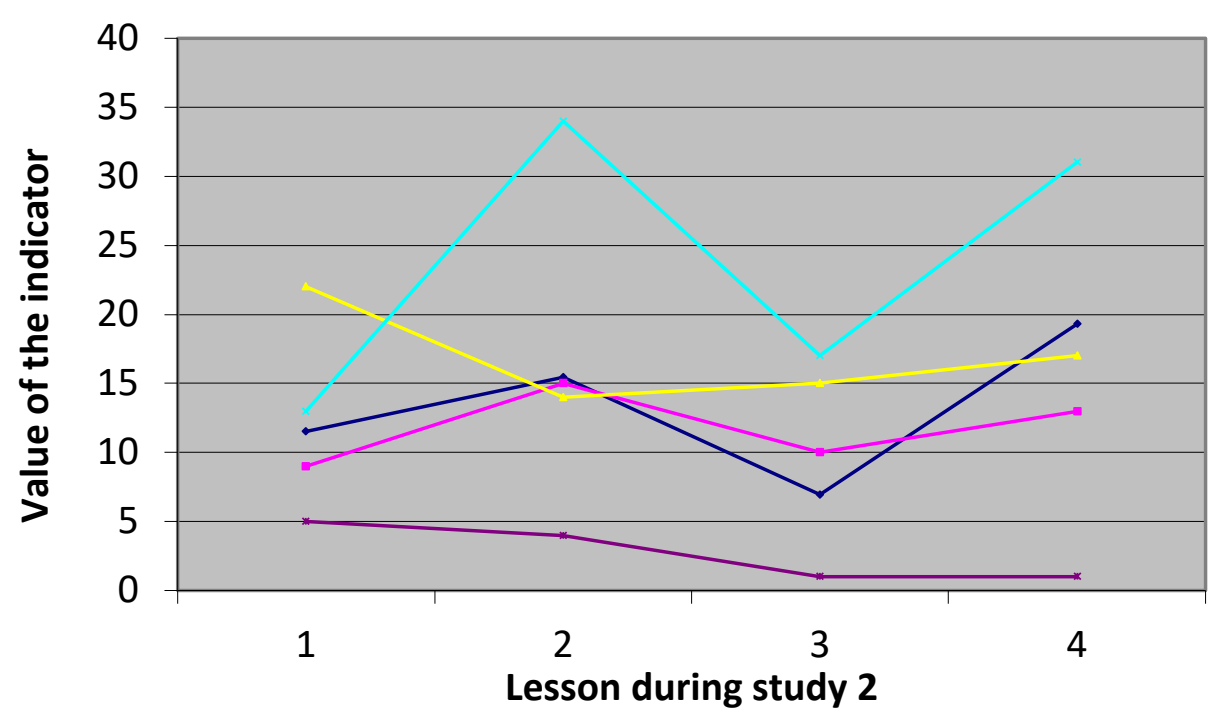

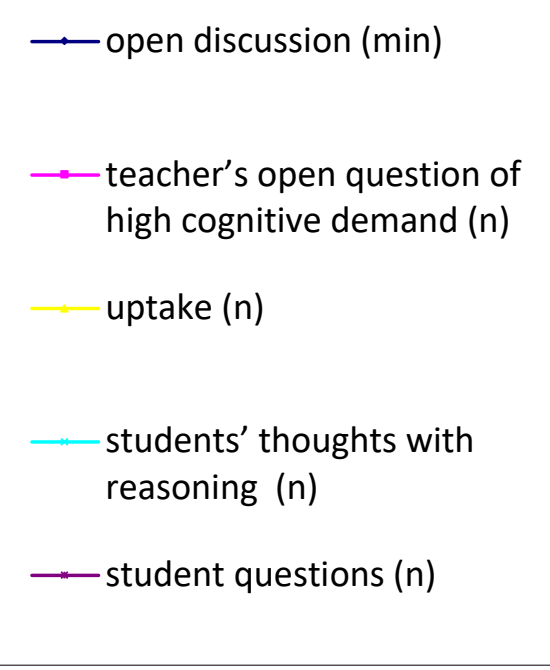

When analyzing the sequence of lessons recorded in 2018, we have to keep in mind that the data was being collected under different conditions than the previous series. In 2014/2015, Daniela was undergoing a teacher development programme; within this frame, achieving the maximal feasible values of indicators was prescribed as a desirable goal. Daniela knew her teaching was assessed by the researchers according to the indicators, and this made her try hard to maximize these indicators in each lesson. In 2018, there was no assignment of this kind. In this project, the researchers asked the teachers to conduct ordinary lessons the way they usually teach. This implies that lower values of indicators in 2018 were expectable.

When we compare Figure 3 with Figure 2, we can see that all of the indicators except student questions are above the lowest values in the 2014/2015 series. The sequence is more balanced - the drops and peaks in most of the indicators are not as steep as in 2014/2015. The fact that the 2018 lessons are equable is of high significance. It can be interpreted as a signal of the routinization of the dialogic approach in Daniela's lessons. Her instructional methods were also simplified. During the TPD program, Daniela was experimenting with diverse methods, looking frantically for what might work; during the follow-up data collection, the structure of the lessons remained nearly the same. The core of the lesson was always a literary text that was read aloud in the class. Students then worked in pairs with sheets prepared by the teacher, answering questions related to the text. Finally, there was a whole-class conversation focused on the interpretation of the text. These three elements (reading, working with sheets, discussing) rotated freely during the observed lessons. Thus, not only the values of indicators but also instructional methods had become stable.

To sum up, the follow-up lessons were characterized by a more favorable structure of dialogic indicators than the pre lessons. However, it cannot be overlooked that the teacher did not surpass all the indicators of the pre-lessons. I will discuss this finding below. The follow-up lessons are more equable than the post lessons, which indicates the sustainability of the accomplished change. 


\section{Changes in teacher's thinking and beliefs}

In this section, I will address RQ 2, looking for what changed from Study 1 to Study 2 in how the teacher thinks about her teaching and students. I will utilize the data from the interviews collected in 2014/2015 and in 2018.

\section{Dialogic teaching as a vehicle for teaching goals}

In 2014/2015, Daniela reported that it was challenging for her to boost student participation and at the same time keep the classroom dialogue purposeful, especially when students were involved in the open discussion (see Sedova, 2017). During Study 1, when the open discussion was established in the class and students reacted to each other, this interaction often distracted from the curricular content or teaching goals of the teacher. Only at the end of the series had Daniela mastered the skill of keeping open discussion purposeful.

At the time of Study 2, there were no visible problems with purposefulness in a discussion. Students discussed a lot; interactions among peers were lively but always linked to the literary texts the class read and interpreted. The teacher explained it as follows:

I am very happy when the lesson is running as I have planned. When I fulfill the curriculum and my intended goals, and at the same time, students are eagerly engaged. This is what I find to be a success. And in this class, this happens very often.

The issues of 'curriculum' and 'intended goals' are very much connected to time and time management. The concern about being under time pressure in order to keep to a plan was repeatedly discussed between Daniela and the researcher during Study 1. However, at the time of Study 2, the teacher considered the problem with time and pacing to have been solved:

\footnotetext{
Formerly, I wanted to do too much in the lesson. I didn't realize that when students start to talk, it would take a lot of time. And sometimes, I drove them forwards and stopped them from talking because I wanted to squeeze another activity in the lesson because that was my plan. And this is what I have learned - it's not always necessary to keep the plan. Sometimes it's more valuable to let kids talk.
}

During Study 2, Daniela did not mention problems with time, curriculum, plans, and pacing at all. On the contrary, she was satisfied with fulfilling her intended goals, as shown in the statement above. Therefore, the concept of intended goals is worth closer examination. When the teacher was talking about her goals in 2018, she was setting them in accordance with dialogic teaching theory, and with the TPD program she had undergone:

\footnotetext{
I want students to be able to reason when talking about the text. Not only to answer questions like 'is this an essay or a report?' I try to give them a word to let them express how they understand what they have read and to discuss it. This is what I learned during the professional development programme.
}

To teach students how to reason or discuss are objectives representative of dialogic teaching. On the other hand, during the interviews in Study 2, Daniela often associated dialogic teaching with very traditional teaching goals that had not been emphasized in the TPD program. For example, she spoke about checking student understanding, teaching students to look up information in a text, and supporting remembering through dialogic teaching: 
When they enter a discussion and explain what they think and why they think so, it causes them to remember much more from the lesson.

This implies that the teacher was utilizing a new approach to fulfilling the traditional goals that she already had before she entered the TPD program. During Study 1, Daniela was repeatedly discontent when using dialogic teaching as this distracted her from what she felt committed to doing (e.g., delivering factual information to students). What happened after she had completed TPD was not a radical shift in what this teacher saw as her objectives by replacing 'old' ones (e.g., remembering) with 'new' ones (e.g., authentic expression). Rather, the newly mastered approach was appropriated to match the formerly established set of goals and achievements. Dialogic teaching started to work as a reliable vehicle for the wide spectrum of Daniela's teaching goals.

\section{Trust in students}

Worries about student capability were apparent in Daniela's thinking at the time of Study 1 , even though the class she taught in 2014/2015 had a good reputation among the teachers and consisted predominantly of high achieving students. She worried about the willingness of students to participate in challenging conversations. This led her to an ongoing deliberation of what degree of cognitive demand is appropriate for not discouraging students from taking part in classroom dialogue. Several times during Study 1, Daniela assessed her questions as too demanding for the students, which - according to her undermined their zest for participation. On the other hand, sometimes her questions and tasks were too low in their demands. The students were enthused by talking, but they hardly learned anything new. When planning her lessons, Daniela repeatedly expressed concern about how students would cope with the learning tasks.

In contrast, the class taught by Daniela in 2018 had a bad reputation among the teachers and consisted predominantly of low-achieving students. Daniela repeatedly mentioned the bad grades of these students, but she did not doubt their capacity for intellectually challenging dialogue at all.

\footnotetext{
This class is not much liked by the teachers. The kids don't have good grades and also had some troubles with relationships in class. But I like them since they are not scared of talking. I like that they are able to express their thoughts, and they are authentic. When talking, they don't make random guesses but apply reasoning, and sometimes really very interesting things emerge in this class.
}

Daniela changed her thinking about the students. In 2014/2015, she saw students as potentially resistant; in 2018, she appreciated student zeal for classroom talk. Moreover, through engaging in talk with these students, she was able to reveal their bright sides. This indicates that the teacher's mindset concerning students and their ability to participate in dialogic conversation changed due to the teacher's experience with dialogic teaching.

The new perception of students seems to be mirrored in Daniela's dealing with the issue of cognitive demand. Her concerns about this had fully disappeared at the time of Study 2. In the 2018 interviews, Daniela repeatedly presented herself as not being afraid of challenging students. For example, there was an energetic student discussion about various theories of world creation in one lesson during Study 2, based on a reading from Sophie's World by Jostein Gaarder. In the interview with the researcher, Daniela commented on this lesson: 
Daniela: They surprised me in how deeply they discussed such complicated topics as the Big Bang theory, et cetera. It surpassed my expectations.

Researcher: Why did you pick such a hard reading for them?

Daniela: To make them think. ((laughing))

It is obvious from the fragment that Daniela intended to challenge students, even when she did not expect them to master the task perfectly. The demand stopped being a problem for her. She sets high standards for her students, but she is not disappointed if the standards are not met.

Self-confidence, enjoying dialogic teaching

In Study 1, teachers participating in the TPD program experienced a variety of emotions, including strong negative ones (for a detailed analysis, see Sedova et al., 2017). Daniela was no exception. During TPD, she expressed a lot of insecurity, anxiety, and disappointment related to her teaching performance. She repeatedly doubted her ability to conduct a proper dialogic lesson; this made her anxious about what would happen in the class.

At the time of Study 2, Daniela presented completely different proclamations:

It is not happening to me anymore that when I ask a question, the kids don't react. When they know that the environment is safe and the others listen to them, they always start talking.

Instead of being nervous about how to make students talk, Daniela expected to be successful in making students talk, and at the same time, she was able to identify key elements that she could safely rely on: a safe environment and respectful listening. When talking about dialogic teaching during Study 2, she mentioned her positive emotions solely; she said it was 'riveting' or 'entertaining' for her, she repeatedly said that she was 'happy' when talking with students.

The 2018 interviews showed that Daniela felt dialogic teaching to be integrated into her teaching repertoire. Moreover, she perceived it to be part of her professional identity.

\footnotetext{
It is very important for me to let students talk in lessons. I always favored it, but after I had completed the program, it started to be my priority. Really. I am very interested in seeing how kids are opening themselves and how they are gradually gaining the ability to express their thoughts. My advantage was that I found myself in the dialogic method. It matched with what I was doing with kids before. And then I saw the incredible outcomes. So, I continue.
}

It is apparent from her statement that Daniela felt dialogic teaching to be compatible with her former mindset. At the same time, she perceived dialogic teaching to be an upgrade of her previous style of teaching, and she was able to identify the benefits of it. This all led her to continue.

\section{Discussion}

In this paper, I studied one teacher's practices and thinking several years after completing a TPD programme on dialogic teaching with the aim of assessing the sustainability of the change accomplished through TPD. I demonstrated that the majority of indicators that the teacher had incorporated into her teaching due to TPD persevered, albeit not at the high level accomplished during TPD. This observation is in accordance with Osborne et al. (2019). My interpretation of the moderate decrease at the follow-up lessons is based on the changed conditions of data gathering. Lessons recorded during Study 1 were taught in the context of an ongoing TPD program - teachers were strongly encouraged to teach in 
compliance with the TPD conception of good teaching as defined by the presence of monitored dialogic teaching indicators. In contrast, the lessons recorded during Study 2 were not a part of any TPD program; the teacher was instructed to teach as she normally does. Therefore, these lessons reflected more the teacher's own conception of what is good. From this perspective, it is clear that Daniela appreciated some of the indicators enough to keep them, but she avoided the extreme values that she was able to reach when being monitored and mentored by the researchers (see Sedova, 2017). Instead of labeling this as unsustainable, I suggest modifying the notion of what the sustainability of TPD effects means.

Not all indicators were improved during TPD and then maintained afterward. The teacher's open questions of high cognitive demand returned to the same frequency as before TPD, and student questions even went down. On the other hand, uptake continued to increase after the completion of TPD. These findings indicate that after some time, the teacher performed dialogic teaching, but not exactly as she had been taught to do: she autonomously re-interpreted and re-created the concept. Some things were accentuated by her, and some things were de-emphasized. Similar findings were presented in a study by Gomez Zaccarelli et al. (2018), who observed one teacher undergoing a long-term TPD program in which participants were taught new teaching practices - asking challenging questions and pressing students to elaborate their reasoning. After the TPD program, the authors found that the focal teacher increased the press moves but reduced the ask moves. Simply said, the teacher prioritized pressing students to elaborate over asking challenging questions.

My findings, as well as those of Gomez Zaccarelli et al. (2018), can be interpreted using the theory by Grossman et al. (1999) of the appropriation of new teaching tools in the process of TPD. According to Grossman et al. (1999), teachers who enter TPD are familiarised with new teaching tools. However, teachers do not adopt teaching tools unmodified. Instead, they tailor the tools to their own needs and preferences, and they creatively complement them to their pre-existing repertoire of skills and knowledge. In the most advanced stage of appropriation, the teacher is able to use the tools effectively and deliberately (Grossman et al., 1999). In this light, we can understand the data from Daniela's follow-up lessons - e.g., strengthening uptake and suppressing student questions. According to Butler et al. (2004), an effective TPD program should allow teachers to try new ideas in an authentic context and find their own way of implementing them in their own practices. Similarly, Silver et al. (2019) claim that teacher understanding of a new instructional strategy needs time to develop and be refined through teacher participation in various types of activities, e.g., through applications of the strategy in the classroom, thinking about possible adaptations, and reflecting on their own implementation. This is what was happening during the TPD program and - as the data indicates - even after its termination when the teacher independently continued in appropriating dialogic teaching; this resulted in the differences between the post and follow-up lessons.

Further, I found that the follow-up lessons were quite consistent, both in terms of the measured indicators and the observed teaching methods. This stability can also be perceived as evidence of the sustainability of the attained dialogic approach to teaching. Daniela mastered the appropriation of the dialogic teaching tools to serve her needs and preferences; the hectic search for innovations and modification was no longer necessary. All these observations indicate that Daniela practiced her professional agency as she made choices and took stances to affect her classroom work and its effects (Eteläpelto et al., 2013). According to Imants \& Van der Wal (2020), teacher agency is a necessary prerequisite for a sustained change in teacher and school development. The teacher participating in this study did not follow all the instructions and suggestions given to her during TPD, but she did establish ways to interact with students that led towards their authentic thinking and participation and maintained the spirit of dialogic teaching. The teacher capacity for agency thus might be significant for sustaining dialogic practices after completing TPD. 
When thinking about the scarcity of dialogic teaching, Hennessy and Davies (2020) identified three general reasons for why the implementation of dialogic teaching practices through TPD might not be sustainable: the unmanageable complexity of the change, the lack of deep shift in teacher mindset, and distrust in dialogic teaching. From the perspective of the data, it is possible to observe how the focal teacher in this study overcame these obstacles.

The problem of complexity was intensely experienced by Daniela during Study 1 . She struggled with disharmony between individual indicators (see Sedova, 2017), had difficulty coordinating the content of classroom discussions with curriculum and her teaching goals, and she felt herself under pressure in terms of time. These observations are in accordance with what has been reported by other authors. Lefstein (2010) argued that the necessity to connect classroom talk to the curriculum prevents teachers from elaborating ideas introduced by students. Similarly, Michaels and O'Connor (2015) reported that teachers experience fear about the content of their discussions and worry that they will not be able to keep the discussions within the boundaries staked by the curriculum. Further, Michaels and O'Connor (2015), as well as Pimentel and McNeil (2013), found that lack of time during lessons inhibits teachers from using the dialogic approach.

I have outlined above how Daniela coped with the complexity of dialogic teaching: she prioritized some of its elements over others. It is interesting that open discussion was difficult for Daniela during TPD; despite this, she persevered with this indicator. This means that she did not abandon what was challenging for her; she acted with an agency to employ the most fruitful tools. When dealing with complexity, Daniela rethought the relationship between the dialogic approach and her teaching goals. She learned how to use dialogic teaching to fulfill the goals she already had before the TPD (to deliver factual information, to make students remember, etc.). On the other hand, she also started to appraise new goals in compliance with the dialogic approach (to let students express their authentic ideas, to teach students to argue, etc.). This made her more relaxed in relation to time planning, as she revealed that letting students express their thoughts is valuable in itself.

In terms of teacher mindset, Butler et al. (2004) reported that the mere development of teachers' practical skills does not necessarily change their teaching if it is not accompanied by a movement in teachers' conceptual knowledge and beliefs. Fecho (2011) claims that there must be a 'wobble' - a shift in the balance in teacher belief systems - to make a deep change in their instructional approach occur. In Daniela's case, the most noticeable transformation was grounded in how she perceived the students. Many authors claim that this is the critical point since many teachers believe that not all students are capable of engaging in challenging dialogue (e.g., Pimentel \& McNeill 2013; Snell \& Lefstein 2018), or they even worry that some students may resist when being invited to a discussion (Michaels \& O'Connor; 2015); this worry stops the teachers from applying dialogic teaching. Daniela changed her mindset concerning students. I think this change was due to her experience during TPD when she was supported by the researchers to invite students in dialogue and to challenge them despite her worries about their talkativeness and their courage to discuss difficult questions. The analysis of the data from Study 1 showed that once participating teachers changed their communication behavior, students answered with corresponding changes. When invited to give elaborated and thoughtful responses with reasoning, students did so (Sedova et al., 2016). I believe that Daniela considered this (during the Study 2 interviews, she spoke about 'incredible outcomes' of dialogic teaching), and this made her believe that she could effectively influence the way students participate in classroom dialogue. At the time of Study 2, her confidence in the students and in their capacity and willingness to engage in the sophisticated talk was strong, and this led her to continue with dialogic teaching. 
The last obstacle against the sustainability of dialogic teaching identified by Hennessy \& Davies (2020) is the distrust in this approach. Even when teachers complete TPD on dialogic teaching, they do not necessarily lose the need to be persuaded about the benefits of this approach. Daniela repeatedly expressed her strong belief in dialogic teaching, stressing she found herself in this way of teaching. The question is what convinced her so strongly. There is evidence that in the eyes of teachers, a strong theoretical foundation legitimizes TPD (Adey, 2006; Butler et al., 2004). We relied on this in the TPD program when we tried to present dialogic teaching as well-founded and provably effective. However, during the interviews, Daniela did not refer to this knowledge base. Another device for making TPD convincing is experimenting with new approaches and teaching tools in authentic classroom situations together with reflection on the teaching experience (see Korthagen et al., 2001). This seemed to work in this case, as Daniela often mentioned her first-hand experience in the classroom as persuading her of the benefits of dialogic teaching. Last but not least, Daniela did not enter the TPD in opposition to ideas related to dialogic teaching. Rather, she had a spontaneous and implicit inclination to this teaching approach, and the TPD program helped her to make it more developed and applicable in the class.

\section{Implications of the study}

This study provides some promising evidence that TPD can be regarded as a tool for delivering dialogic teaching in classes, even from a long-term perspective. This is an important message, as TPD programs, especially those based on intensive collaboration between teachers and their educators (e.g., through making video recordings and reflecting on them), are costly and demand a lot of time and effort both from teachers and their educators.

The analysis in this study provides evidence that the obstacles against dialogic teaching TPD programs identified by Hennessy and Davies (2020) are fitting. The focal teacher was contending with all of these obstacles; this study concerns how she overcame them. This implies that when designing TPD programs on dialogic teaching, the issues of complexity, teacher mindset, and trust should be taken into careful consideration.

Finally, this study shows that making dialogic teaching sustainable requires allowing teachers to re-create and re-interpret the concept and teaching tools in the process of their appropriation (Grossman et al., 1999). This means not only giving teachers enough space to acquire and consider the first-hand experience with how the tools work in their classes but also applying a sensitive stance in judging whether the teachers properly utilized the support given to them in TPD.

I opened this study by claiming that the issue of the sustainability of the change towards dialogic teaching has been rarely investigated and that this paper was to contribute to this underexplored field. However, this study is only a very small contribution to the question of the sustainability of dialogic teaching. With regard to the importance of this topic for the legitimization of dialogic teaching TPD efforts, it is necessary to build a coherent research line in this field.

\section{References}

Adey, P. (2006). A model for professional development of teachers thinking. Thinking Skills and Creativity, 1(1), 49-56. doi:10.1016/j.tsc.2005.07.002

Alexander, R. J. (2006). Towards dialogic teaching: Rethinking classroom talk. Cambridge: Dialogos.

Alexander R. J. (2008) Essays on pedagogy. Routledge: New York

Alexander, R. J. (2018). Developing dialogue: Genesis, process, trial. Research Papers in Education, 33(5), 561-598. doi:10.1080/02671522.2018.1481140 
Alexander, R. J. (2020). A dialogic teaching companion. Abingdon, United Kingdom: Routledge.

Andreassen, R., \& Bråten, I. (2011). Implementation and effects of explicit reading comprehension instruction in fifth-grade classrooms. Learning and Instruction, 21(4), 520-537. doi:10.1016/j.learninstruc.2010.08.003

Applebee, A. N., Langer, J. A., Nystrand, M., \& Gamoran, A. (2003). Discussion-based approaches to developing understanding: Classroom instruction and student performance in middle and high school English. American Educational Research Journal, 40(3), 685-730. doi:10.3102/00028312040003685

Bakhtin, M. M. (1981). The dialogic imagination: Four essays. University of Texas Press, Austin.

Berry, R. A. W., \& Kim, N. (2008). Exploring teacher talk during mathematics instruction in an inclusion classroom. The Journal of Educational Research, 101(6), 363-378. doi:10.3200/JOER.101.6.363-378

Butler, D. L., Novak Lauscher, H., Jarvis-Selinger, S., \& Beckingham, B. (2004). Collaboration and selfregulation in teachers' professional development. Teaching and Teacher Education, 20(5), 435455. doi:10.1016/j.tate.2004.04.003

Chen, G. (2020). A visual learning analytics (VLA) approach to video-based teacher professional development: Impact on teachers' beliefs, self-efficacy, and classroom talk practice. Computers and Education, 144, 103670. doi: 10.1016/j.compedu.2019.103670

Chinn, C. A., Anderson R. C., \& Waggoner, M. A. (2001). Patterns of discourse in two kinds of literature discussion. Reading Research Quarterly, 36(4), 378-411. doi:10.1598/RRQ.36.4.3

Crick, R. D., McCombs, B., Haddon, A., Broadfoot P. \& Tew, M. (2007). The ecology of learning: factors contributing to learner-centered classroom cultures, Research Papers in Education, 22(3), 267307, doi: 10.1080/02671520701497555

Eteläpelto, A., Vähäsantanen, K., Hökkä, P., \& Paloniemi, S. (2013). What is agency? Conceptualizing professional agency at work. Educational Research Review, 10, 45-65. doi: 10.1016/j.edurev.2013.05.001

Fecho, B. (2011). Teaching for the Students. Habits of Heart, Mind and Practice in the Engaged Classroom. New York: Teachers College Press.

Gayle, B. M., Preiss, R. W., \& Allen, M. (2006). How effective are teacher-initiated classroom questions in enhancing student learning? In B. M. Gayle, R. W. Preiss, N. Burrell \& M. Allen (Eds.), Classroom communication and instructional processes (pp. 279-293). Mahwah: Lawrence Erlbaum Associates.

Gomez Zaccarelli, F., Schindler A.-K., Borko, H., \& Osborne, J. (2018). Learning from professional development: A case study of the challenges of enacting productive science discourse in the classroom. Professional Development in Education, 44(5), 721-737. doi:10.1080/19415257.2017.1423368

Gore, J., Lloyd, A., Smith, M., Bowe, J., Ellis, H., \& Lubans, D. (2017). Effects of professional development on the quality of teaching: Results from a randomised controlled trial of Quality Teaching Rounds. Teaching and Teacher Education, 68, 99-113. doi:10.1016/j.tate.2017.08.007

Grossman, P. L., Smagorinski, P., \& Valencia, S. (1999). Appropriating tools for teaching English: A theoretical framework for research on learning to teach. American Journal of Education, 108(1), 1-29. doi:10.1086/444230 
Hardman, F., Smith, F., \& Wall, K. (2003). 'Interactive whole class teaching' in the National Literacy Strategy. Cambridge Journal of Education, 33(2), 197-215. doi:10.1080/0305764032000082839

Hennessy, S., \& Davies, M. (2020). Teacher professional development to support classroom dialogue: Challenges and promises. In N. Mercer, R. Wegerif \& L. Major (Eds.), The Routledge international handbook of research on dialogic education (pp. 238-253). Abingdon, United Kingdom: Routledge.

Hennessy, S., Dragovic, T., \& Warwick, P. (2018). A research-informed, school-based professional development workshop programme to promote dialogic teaching with interactive technologies. Professional Development in Education, 44(2), 145-168. doi:10.1080/19415257.2016.1258653

Howe, C., Hennessy, S., Mercer, N., Vrikki, M., \& Wheatley, L. (2019). Teacher-student dialogue during classroom teaching: Does it really impact on student outcomes? Journal of the Learning Sciences, 28(4-5), 462-512. doi:10.1080/10508406.2019.1573730

Imants, J., \& Van der Wal, M. M. (2020) A model of teacher agency in professional development and school reform. Journal of Curriculum Studies, 52(1), 1-14. doi: 10.1080/00220272.2019.1604809

Kim, M.-Y., \& Wilkinson, I. A. G. (2019). What is dialogic teaching? Constructing, deconstructing, and reconstructing a pedagogy of classroom talk. Learning, Culture and Social Interaction, 21, 70-86. doi:10.1016/j.Icsi.2019.02.003

Korthagen, F. A. J., Kessels, J., Koster, B., Lagerwerf, B., \& Wubbels T. (2001). Linking practice and theory: The pedagogy of realistic teacher education. Mahwah: Lawrence Erlbaum Associates.

Lefstein, A. (2010). More helpful as problem than solution: Some implications of situating dialogue in classrooms. In K. Littleton \& C. Howe (Eds.), Educational dialogues: Understanding and promoting productive interaction (pp. 171-190). Abingdon, United Kingdom: Routledge.

Lefstein, A., \& Snell, J. (2014). Better than best practice: Developing teaching and learning through dialogue. Abingdon, United Kingdom: Routledge.

Lyle, S. (2008). Dialogic teaching: Discussing theoretical context and reviewing evidence from classroom practice. Language and Education, 22(3), 222-240. doi:10.2167/le778.0

Mameli, C., Grazia, V., Molinari, L. (2020). Agency, responsibility and equity in teacher versus studentcentred school activities: A comparison between teachers' and learners' perceptions. Journal of Educational Change, 21(2), 345-361. doi: 10.1007/s10833-019-09366-y

McElhone, D. (2012). Tell us more: Reading comprehension, engagement, and conceptual press discourse. Reading Psychology, 33(6), 525-561. doi:10.1080/02702711.2011.561655

Mercer, N. (2008). The guided construction of knowledge: Talk among teachers and learners. Clevedon: Multilingual Matters.

Michaels, S., \& O'Connor, C. (2015) Conceptualizing talk moves as tools: Professional development approaches for academically productive discussions. In L. B. Resnick, C. S. C. Asterhan \& S. N. Clarke (Eds.), Socializing intelligence through academic talk and dialogue (pp. 333-347). Washington, D. C.: American Educational Research Association Press.

Muhonen, H., Pakarinen, E., Poikkeus, A.-M., Lerkkanen, M.-K., \& Rasku-Puttonen, H. (2018). Quality of educational dialogue and association with students' academic performance. Learning and Instruction, 55, 67-79. doi:10.1016/j.learninstruc.2017.09.007 
Murphy, P. K., Wilkinson, I. A. G., Soter, A. O., Hennessey, M. N., \& Alexander, J. F. (2009). Examining the effects of classroom discussion on students' comprehension of text: A meta-analysis. Journal of Educational Psychology, 101(3), 740-764. doi:10.1037/a0015576

Nassaji, H., \& Wells, G. (2000). What's the use of 'triadic dialogue'? An investigation of teacher-student interaction. Applied Linguistics, 21(3), 376-406. doi:10.1093/applin/21.3.376

Nystrand, M., Gamoran, A., Kachur, R., \& Prendergast, C. (1997). Opening dialogue: Understanding the dynamics of language and learning in the English classroom. New York: Teachers College Press.

Nystrand, M., Wu, L. L., Gamoran A., Zeiser, S., \& Long, D. (2001). Questions in time: Investigating the structure and dynamics of unfolding classroom discourse. CELA Research Report $n^{\circ} 14005$. Albany: The National Research Center on English Learning \& Achievement.

O'Connor, C., Michaels, S., \& Chapin, S. (2015). 'Scaling down' to explore the role of talk in learning: From district intervention to controlled classroom study. In L. B. Resnick, C. S. C. Asterhan \& S. N. Clarke (Eds.), Socializing intelligence through academic talk and dialogue (pp. 111-126). Washington, D. C.: American Educational Research Association Press.

Osborne, J. F., Borko, H., Fishman, E., Gomez Zaccarelli, F., Berson, E., Busch, K. C., Reigh, E., \& Tseng, A. (2019). Impacts of a practice-based professional development program on elementary teachers' facilitation of and student engagement with scientific argumentation. American Educational Research Journal, 56(4), 1067-1112. doi:10.3102/0002831218812059

Pimentel, D. S., \& McNeill, K. L. (2013). Conducting talk in secondary science classrooms: Investigating instructional moves and teachers' beliefs. Science Education, 97(3), 367-394. doi:10.1002/sce.21061

Reisman, A., Enumah, L. (2020). Using Video to Highlight Curriculum-Embedded Opportunities for Student Discourse. Journal of Teacher Education, online first. doi: 10.1177/0022487119895503

Resnick, L. B., Asterhan, C. S. C., \& Clarke, S. (2018). Next generation research in dialogic learning. In G. E. Hall, L. F. Quinn \& D. M. Gollnick (Eds), The Wiley handbook of teaching and learning (pp. 323-338). Hoboken: John Wiley \& Sons.

Schwarz, B. B., Cohen, I., \& Ophir, Y. (2017). The epidemic effect of scaffolding argumentation in small groups to whole-class teacher-led argumentation. In F. Arcidiacono \& A. Bova (Eds.), Interpersonal argumentation in educational and professional contexts (pp. 95-115). Cham, Switzerland: Springer.

Sedova, K. (2017). A case study of a transition to dialogic teaching as a process of gradual change. Teaching and Teacher Education, 67, 278-290. doi: 10.1016/j.tate.2017.06.018

Sedova, K., Salamounova, Z., \& Svaricek, R. (2014). Troubles with dialogic teaching. Learning, Culture and Social Interaction, 3(4), 274-285. doi: 10.1016/j.Icsi.2014.04.001

Sedova, K., Salamounova, Z., Svaricek, R., \& Sedlacek, M. (2017). Teachers' Emotions in Teacher Development: Do They Matter? Studia paedagogica, 22(4), 77-110. doi 10.5817/SP2017-4-5

Sedova, K., Sedlacek, M., \& Svaricek, R. (2016). Teacher professional development as a means of transforming student classroom talk. Teaching and teacher education, 57, 14-25. doi: 10.1016/j.tate.2016.03.005

Sedova, K., Sedlacek, M., Svaricek, R., Majcik, M., Navratilova, J., Drexlerova, A., ... \& Salamounova, Z. (2019). Do those who talk more learn more? The relationship between student classroom talk and 
student achievement. Learning and Instruction, 63, 101217. doi:

10.1016/j.learninstruc.2019.101217

Silver, R. E., Kogut, G., Huynh, T. C. D. (2019). Learning “New” Instructional Strategies: Pedagogical Innovation, Teacher Professional Development, Understanding and Concerns. Journal of Teacher Education, 70(5), 552-566. doi: 10.1177/0022487119844712

Snell, J., \& Lefstein, A. (2018). 'Low ability,' participation, and identity in dialogic pedagogy. American Educational Research Journal, 55(1), 40-78. doi:10.3102/0002831217730010

Strauss, A., \& Corbin, J. (1990). Basic of grounded theory methods. Beverly Hills: SAGE.

Vrikki, M., Wheatley, L., Howe, C., Hennessy, S., \& Mercer, N. (2019). Dialogic practices in primary school classrooms. Language and Education, 33(1), 85-100.

doi:10.1080/09500782.2018.1509988

Vygotsky, L. S. (1978). Mind in society: The development of higher psychological processes. Harvard University Press, Cambridge.

Wells, G., \& Arauz, R. M. (2006). Dialogue in the classroom. The Journal of the Learning Sciences, 15(3), 379-428. doi:10.1207/s15327809jls1503_3

Wertsch, J. V. (1985). Vygotsky and the social formation of mind. Harvard University Press, Cambridge.

\section{Appendix 1: Overview of data sources used in this paper}

\begin{tabular}{|l|l|l|}
\hline Study & Videorecordings of lessons & Interviews with teacher \\
\hline Study 1 & 10 & 6 \\
\hline Study 2 & 4 & 2 \\
\hline
\end{tabular}

Appendix 2: Deductive system for coding classroom dialogue (data from videorecordings)

\begin{tabular}{|l|l|l|l|l|}
\hline Indicator & Description & Illustration from the data set & $\begin{array}{l}\text { Incidence } \\
\text { in Study 1 } \\
\text { (10 } \\
\text { lessons) }\end{array}$ & $\begin{array}{l}\text { Incidence } \\
\text { in Study 2 } \\
\text { (4 lessons) }\end{array}$ \\
\hline $\begin{array}{l}\text { student } \\
\text { thoughts with } \\
\text { reasoning }\end{array}$ & $\begin{array}{l}\text { student utterance that } \\
\text { resembles a sentence } \\
\text { and includes } \\
\text { explanation }\end{array}$ & $\begin{array}{l}\text { Teacher: So, can you tell me why you } \\
\text { think that Aragorn is a hero? } \\
\text { Student: It seems to me that he was } \\
\text { afraid at first, but he overcame this and } \\
\text { led the army into a battle, a victorious } \\
\text { battle, and he just decided to take on } \\
\text { this burden and by that he helped } \\
\text { everyone to succeed. }\end{array}$ & 173 & 95 \\
\hline $\begin{array}{l}\text { teacher's open } \\
\text { questions of } \\
\text { high cognitive } \\
\text { demand }\end{array}$ & $\begin{array}{l}\text { authentic question with } \\
\text { many possible answers } \\
\text { requiring logical } \\
\text { thought }\end{array}$ & $\begin{array}{l}\text { Teacher: So, can you tell me why you } \\
\text { think that Aragorn is a hero? }\end{array}$ & 225 & 47 \\
\hline
\end{tabular}




\begin{tabular}{|c|c|c|c|c|}
\hline uptake & $\begin{array}{l}\text { the teacher poses a } \\
\text { new question to the } \\
\text { student, based on } \\
\text { his/her previous } \\
\text { answer }\end{array}$ & $\begin{array}{l}\text { Teacher: So, would you like to see the } \\
\text { corrida? } \\
\text { Student: Yeah. } \\
\text { Teacher: Why yes? } \\
\text { Student: Um, because it's nice. } \\
\text { Teacher: And what is nice? Try, try to } \\
\text { tell me what is nice about it? }\end{array}$ & 128 & 68 \\
\hline $\begin{array}{l}\text { student } \\
\text { questions }\end{array}$ & $\begin{array}{l}\text { question posed by a } \\
\text { student }\end{array}$ & $\begin{array}{l}\text { Student: Why does the author use so } \\
\text { many weird words? }\end{array}$ & 86 & 11 \\
\hline $\begin{array}{l}\text { open } \\
\text { discussion }\end{array}$ & $\begin{array}{l}\text { sequence that includes } \\
\text { at least three } \\
\text { participants who react } \\
\text { to each other for more } \\
\text { than } 30 \text { seconds }\end{array}$ & $\begin{array}{l}\text { Teacher: Why do you think that this } \\
\text { behaviour of Don Quixote is } \\
\text { nonsensical? } \\
\text { Student 1: That somebody has been } \\
\text { building a mill for half a year to be able } \\
\text { to mill flour and this knight comes } \\
\text { there and starts, starts to destroy this } \\
\text { mill. Does that make sense? } \\
\text { Student 2: No. } \\
\text { Student 3: He is paranoid. } \\
\text { Student 2: Yeah, exactly. } \\
\text { Student 4: I think that every activity or } \\
\text { every human behaviour has some } \\
\text { meaning. } \\
\text { Student 1: Just because somebody } \\
\text { thinks that what they do is meaningful } \\
\text { does not mean that it is really } \\
\text { meaningful. } \\
\text { Student 4: But it is meaningful for this } \\
\text { person. }\end{array}$ & $\begin{array}{l}32,85 \\
\text { minutes }\end{array}$ & $\begin{array}{l}53,22 \\
\text { minutes }\end{array}$ \\
\hline
\end{tabular}

\section{Appendix 3: Interview coding procedure}

\section{Phase 1 and 2}

\begin{tabular}{|l|l|l|l|l|}
\hline $\begin{array}{l}\text { Deductive } \\
\text { category }\end{array}$ & Description of the category & $\begin{array}{l}\text { Example of } \\
\text { inductive code } \\
\text { within the } \\
\text { category }\end{array}$ & $\begin{array}{l}\text { Illustration from the data } \\
\text { set }\end{array}$ & $\begin{array}{l}\text { Number of } \\
\text { inductive } \\
\text { codes within } \\
\text { the category }\end{array}$ \\
\hline $\begin{array}{l}\text { complexity } \\
\text { of the } \\
\text { change }\end{array}$ & $\begin{array}{l}\text { Teacher is talking about } \\
\text { how demanding the } \\
\text { change is, what the } \\
\text { obstacles are, what the } \\
\text { cost of the changes is. }\end{array}$ & $\begin{array}{l}\text { time } \\
\text { consideration }\end{array}$ & $\begin{array}{l}\text { Formerly, I wanted to do too } \\
\text { much in the lesson. I didn't } \\
\text { realise that when students } \\
\text { start to talk it would take a } \\
\text { lot of time. }\end{array}$ & 18 \\
\hline $\begin{array}{l}\text { teacher } \\
\text { mindset }\end{array}$ & $\begin{array}{l}\text { Teacher reveals her beliefs } \\
\text { about students and } \\
\text { curriculum. }\end{array}$ & $\begin{array}{l}\text { student } \\
\text { talkativeness } \\
\text { that the environment is safe } \\
\text { and the others listen to } \\
\text { them, they always start } \\
\text { talking. }\end{array}$ & 29 \\
\hline
\end{tabular}




\begin{tabular}{|c|c|c|c|c|}
\hline $\begin{array}{l}\text { (dis)trust in } \\
\text { dialogic } \\
\text { teaching }\end{array}$ & $\begin{array}{l}\text { Teacher expresses beliefs } \\
\text { about potential benefits of } \\
\text { dialogic teaching. Teacher } \\
\text { is considering the effects } \\
\text { of dialogic teaching in her } \\
\text { classroom. }\end{array}$ & Talk focus & $\begin{array}{l}\text { It is very important for me to } \\
\text { let students talk in lessons. I } \\
\text { always favoured it, but after } \\
\text { I had completed the } \\
\text { programme, it started to be } \\
\text { my priority. }\end{array}$ & 22 \\
\hline
\end{tabular}

\section{Phase 3}

\begin{tabular}{|l|l|l|l|l|}
\hline $\begin{array}{l}\text { Inductive } \\
\text { category }\end{array}$ & Description of the category & $\begin{array}{l}\text { Example of } \\
\text { inductive code } \\
\text { within the } \\
\text { category }\end{array}$ & $\begin{array}{l}\text { Illustration from the data } \\
\text { set }\end{array}$ & $\begin{array}{l}\text { Number of } \\
\text { inductive } \\
\text { codes within } \\
\text { the category }\end{array}$ \\
\hline $\begin{array}{l}\text { educational } \\
\text { goals }\end{array}$ & $\begin{array}{l}\text { Changes in how educational } \\
\text { goals are perceived, set, } \\
\text { and evaluated by the } \\
\text { teacher. }\end{array}$ & $\begin{array}{l}\text { time } \\
\text { consideration }\end{array}$ & $\begin{array}{l}\text { Formerly, I wanted to do } \\
\text { too much in the lesson. I } \\
\text { didn't realise that when } \\
\text { students start to talk it } \\
\text { would take a lot of time. }\end{array}$ & 21 \\
\hline students & $\begin{array}{l}\text { Changes in beliefs about } \\
\text { students, experiences with } \\
\text { student behaviour in } \\
\text { dialogic lessons, } \\
\text { consideration of student } \\
\text { achievement }\end{array}$ & $\begin{array}{l}\text { student } \\
\text { talkativeness }\end{array}$ & $\begin{array}{l}\text { When they (students) know } \\
\text { that the environment is } \\
\text { safe and the others listen to } \\
\text { them, they always start } \\
\text { talking. }\end{array}$ & 22 \\
\hline $\begin{array}{l}\text { teacher self- } \\
\text { perception }\end{array}$ & $\begin{array}{l}\text { Changes in how teacher } \\
\text { perceives herself, her } \\
\text { professional competencies, } \\
\text { self-efficacy, and the } \\
\text { potential for further } \\
\text { development }\end{array}$ & talk focus & $\begin{array}{l}\text { It is very important for me } \\
\text { to let students talk in } \\
\text { lessons. I always favoured } \\
\text { it, but after I had completed } \\
\text { the program it started to be } \\
\text { my priority. }\end{array}$ & 26 \\
\hline
\end{tabular}

\section{(cc) EY}

New articles in this journal are licensed under a Creative Commons Attribution 4.0 United States License.

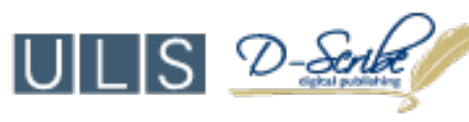

This journal is published by the University Library System, University of Pittsburgh as part of its D-Scribe Digital Publishing Program and is cosponsored by the University of Pittsburgh Press. 